\title{
Interleukin 12 gene polymorphisms enhance gastric cancer risk in $H$ pylori infected individuals
}

\author{
F Navaglia, D Basso, C-F Zambon, E Ponzano, L Caenazzo, N Gallo, A Falda, C Belluco, P Fogar, \\ E Greco, F Di Mario, M Rugge, M Plebani
}

B acterial, environmental, population related, and individual host factors are major determinants of the outcome of $H$ pylori infection. ${ }^{12}$ Many bacterial virulence genesincluding the pathogenicity island $c a g A$, the $\mathrm{s} \operatorname{lml} \mathrm{vac} A$ alleles, babA2, sabA, and oipA-have been associated with a higher degree of gastric mucosal inflammation, intestinal metaplasia, gastric or duodenal ulcer, gastric adenocarcinoma, and MALToma. ${ }^{13-7} \mathrm{H}$ pylori triggers and maintains gastric mucosal inflammation by different mechanisms, which are partly strain dependent and partly strain independent. ${ }^{1} \mathrm{~T}$ and $\mathrm{B}$ lymphocyte activation and infiltration of the gastric mucosa depend on $H$ pylori antigen processing. The number of infiltrating polymorphonuclear cells varies depending on the virulence of the infecting strain, being much greater when infections are caused by cagA positive strains. ${ }^{35}$ 7-9

The inflammatory cells infiltrating $H$ pylori infected gastric mucosa produce a pattern of proinflammatory cytokines. ${ }^{10}{ }^{11}$ High mucosal levels of mononuclear cytokines (IL8, IL6, ILI $\beta$, tumour necrosis factor $\alpha$ (TNF $\alpha)$, and interferon $\gamma$ $($ IFN $\gamma)$ ) and lymphocytic derived cytokines (IL2, IL2R) have been described in $H$ pylori infected patients. ${ }^{10-13} H$ pylori infection also induces the production of IL12, ${ }^{14-16}$ a heterodimeric proinflammatory protein that triggers the production of IFN $\gamma$ and favours the differentiation of T helper 1 (Thl) cells, ${ }_{17}^{18}$ which, in H pylori infected mucosa, prevail over Th2 cells. $^{151619}$ The ability of IL12 to induce Thl is one of the biological bases of the importance of this cytokine in resisting most bacteria, including $H$ pylori, and also intracellular protozoa and fungal pathogens. ${ }^{18} 2021$ Cellular sources of IL12 in response to infections are mainly dendritic cells and phagocytes. ${ }^{16-21}$ The two subunits of IL12-p35 and p40-are encoded by different genes, named IL12A and IL12B respectively, which are unrelated and are located on separate chromosomes (3pl2-q13.2 and 5q31-33). ${ }^{18}$

Host cytokine gene polymorphisms may be as important as exogenous stimuli in influencing the amount of cytokines produced and consequently the pattern and severity of inflammation. ${ }^{102-26}$ IL12 gene polymorphisms in particular have been observed to affect autoimmune diabetes ${ }^{27}$ and atopic and non-atopic asthma. ${ }^{28}$ Both $I L 12 A$ and $I L 12 B$ have a polymorphic dinucleotide repeat region (CT for IL12A and TG-TA for $I L 12 B$ ) in introns 6 and 4, respectively (Gene bank accession numbers: AF404773 for IL12A and AY008847 for $I L 12 B)$, which might affect the amount of the synthesised cytokine. No data have been reported on the possible influence of $I L 12 A$ and $I L 12 B$ polymorphisms on $H$ pylori infection and its outcome.

Our aims in the present study were, first, to use denaturating high performance liquid chromatography (DHPLC) to screen the promoters and the coding sequences of $I L 12 A$ and $I L 12 B$ in order to identify any single nucleotide polymorphisms (SNPs); second, to analyse the SNPs identified, together with the number of CT and TG-TA dinucleotide repeats (variable number tandem repeats (VNTR)) of IL12A

\section{Key points}

- IL12, formed from p35 and p40 subunits encoded by ILI2A and ILI2B genes, favours Thelper 1 (Th I) differentiation. Th1 lymphocytes prevail over Th2 in $H$ pylori associated chronic gastritis, the first step in $H$ pylori associated gastric carcinogenesis. In this study, 110 patients with non-cardia gastric cancer were compared with 251 patients with benign gastroduodenal diseases to see whether there was any correlation between IL12 gene polymorphisms and $H$ pylori associated gastric adenocarcinoma.

- Two single nucleotide polymorphisms were identified on ILI2A (-504 T/G and +6686 A/G) and one on IL12B (+15485 A/G). Eleven and six alleles were found for CT and TG-TA dinucleotide repeats (VNTR) of IL 12A intron 6 and IL 12B intron 4, respectively.

- The frequency of non-cardia gastric cancer was higher in patients with the ILI2A $-504 \mathrm{~T} / \mathrm{T}$ lodds ratio $(O R)=2.38$ ) or with the IL $12 B$ VNTR $(T G-T A)_{9} /(T G-$ $T A)_{11}$ genotype $(O R=1.36)$.

- No IL12 gene polymorphisms were correlated with intestinal metaplasia.

- These findings suggest that ILI2A and ILI2B gene polymorphisms may affect the final steps in gastric carcinogenesis in $\mathrm{H}$ pylori infected subjects.

intron 6 and $I L 12 B$ intron 4 in patients with or without $H$ pylori infection; and third, to verify the association, if any, between the IL12 gene polymorphisms studied and the outcome of $H$ pylori infection (gastric adenocarcinoma in particular).

\section{METHODS}

We studied 251 unrelated Italian patients (112 male, 139 female; age range 27 to 88 years) who consecutively underwent upper gastrointestinal endoscopy (EGDS, (o)esophagogastroduodenoscopy) for dyspeptic symptoms. Diagnoses made on the basis of endoscopic findings were: absence of evident endoscopic lesions (10); antral gastritis (94); diffuse gastritis (57); duodenal ulcer (30); gastric ulcer (10); duodenitis (22); reflux gastritis (16); oesophagitis (12).

Three antral and two body biopsies were obtained at endoscopy from each patient for histological evaluation. Two antral and one body biopsy were also obtained for $H$ pylori

Abbreviations: DHPLC, denaturating high performance liquid chromatography; EGDS, (o)esophagogastroduodenoscopy; IL, interleukin; SNP, single nucleotide polymorphism; Th, T helper; VNTR, variable number tandem repeats 
Table 1 Primer sequences, primer spanning regions, amplified regions, and temperatures of denaturating high performance liquid chromatography analysis

\begin{tabular}{|c|c|c|c|}
\hline Primer sequences & Primer spanning region & Regions & $\begin{array}{l}\text { Temp for DHPLC } \\
\left.\text { analysis ( }{ }^{\circ} \mathrm{C}\right)\end{array}$ \\
\hline \multicolumn{4}{|l|}{ IL12A (p35) } \\
\hline $5^{\prime}$ tccccactactctcagcaca $3^{\prime}$ & $-941 /-922$ & \multirow{2}{*}{ Promoter } & \multirow[b]{2}{*}{$63 ; 64$} \\
\hline $5^{\prime}$ cgataggatgaatacacagagtcc $3^{\prime}$ & $-598 /-621$ & & \\
\hline $5^{\prime}$ ggagcctttgctgactcct $3^{\prime}$ & $-693 /-675$ & \multirow{2}{*}{ Promoter } & \multirow{2}{*}{59.6} \\
\hline 5'ggacacccagggagaacag $3^{\prime}$ & $-451 /-469$ & & \\
\hline $5^{\prime}$ 'tgtgaacaaaacgccttgag $3^{\prime}$ & $-520 /-501$ & \multirow{2}{*}{ Promoter } & \multirow{2}{*}{61.8} \\
\hline $5^{\prime}$ gcccogtgtctaagctacc $3^{\prime}$ & $-241 /-259$ & & \\
\hline 5' gggagg cactcctctctcta $3^{\prime}$ & $-313 /-294$ & \multirow{2}{*}{ Promoter } & \multirow{2}{*}{$65.5 ; 67$} \\
\hline $5^{\prime}$ cggcgcttcggattaact $3^{\prime}$ & $-71 /-89$ & & \\
\hline 5' actgcgaacatttcgctttc 3' & $-171 /-152$ & \multirow{2}{*}{ Promoter } & \multirow{2}{*}{69.3} \\
\hline $\begin{array}{l}\text { 5'acatcagcttctcggtgaca } 3^{\prime} \\
5^{\prime} \text { cagqagttaatccgaaagc } 3^{\prime}\end{array}$ & $\begin{array}{l}-22 /-41 \\
-93 /-75\end{array}$ & & \\
\hline $\begin{array}{l}5^{\prime} \text { cgggagttaatccgaaagc } 3^{\prime} \\
5^{\prime} \text { cgctggatgcagacctgt } 3^{\prime}\end{array}$ & $\begin{array}{l}-93 /-75 \\
+129 /+112\end{array}$ & Promoter and exon 1 & 63.8 \\
\hline $5^{\prime}$ agtcccgggaaagtcctg $3^{\prime}$ & $+19 /+36$ & \multirow{2}{*}{ Exon 1} & \multirow{2}{*}{$65.0 ; 67.0$} \\
\hline 5'gagcgagccaaagacctg $3^{\prime}$ & $+213 /+196$ & & \\
\hline $5^{\prime}$ atccaggctgaagctcctc $3^{\prime}$ & $+1130 /+1148$ & \multirow{2}{*}{ Exon 2} & \multirow{2}{*}{63.2} \\
\hline 5'gagggtgcaggtccacag $3^{\prime}$ & $+1357 /+1340$ & & \\
\hline 5'ggtgccaggtgcattatcaa3' & $+3961 /+3980$ & \multirow{2}{*}{ Exon 3} & \multirow{2}{*}{$56.9 ; 57.9$} \\
\hline $5^{\prime}$ thtaaccacactgcatgctc $3^{\prime}$ & $+4171 /+4151$ & & \\
\hline 5'ttgagacctgaagagtcagaaaga 3 ' & $+4385 /+4408$ & & \\
\hline $5^{\prime}$ cccattg catttgaggaaag $3^{\prime}$ & $+4648 /+4629$ & Exon 4 and exon 5 & $56.2 ; 57.8$ \\
\hline $5^{\prime}$ tggatacttccccatcttgtc $3^{\prime}$ & $+4673 /+4693$ & & \\
\hline 5' gcatgaaaaaggtgctctca $3^{\prime}$ & $+4888 /+4869$ & Exon 6 & 58.7 \\
\hline $5^{\prime}$ ttggaataccatgtaagtcatgc $3^{\prime}$ & $+6368 /+6390$ & & \\
\hline $5^{\prime}$ tgatcagaggtatcatgtggatg $3^{\prime}$ & $+6699 /+6677$ & Exon 7 and UTR & $56.1 ; 57.4$ \\
\hline 5'gaactagggagggggaaaga3' & $+6642 /+6661$ & & \\
\hline $5^{\prime}$ gctcagatgctttcatgattacc $3^{\prime}$ & $+6924 /+6902$ & UIR & 55.0 \\
\hline IL12B (p40) & & & \\
\hline 5' ggaaagttageccggaaatc $3^{\prime}$ & $-1246 /-1227$ & & \\
\hline $5^{\prime}$ accaggtacacgcagacaga $3^{\prime}$ & $-983 /-1002$ & Promoter & $66.0 ; 68.0$ \\
\hline $5^{\prime}$ gtctcgcagcgacctctgt $3^{\prime}$ & $-1045 /-1027$ & & \\
\hline $5^{\prime}$ tgctaagaggtatgcaaaggtg $3^{\prime}$ & $-892 /-913$ & Promoter & $64.6 ; 65.6$ \\
\hline $5^{\prime}$ ttcctgttcacgtgcagact $3^{\prime}$ & $-965 /-946$ & & \\
\hline 5'cggatgggagcagaaagtg 3 ' & $-707 /-725$ & Promoter & 60.7 \\
\hline $5^{\prime}$ gccttgagtgtggitgtctg $3^{\prime}$ & $-766 /-747$ & & 603.630 \\
\hline $5^{\prime}$ 'ttaccacccatcttggctc $3^{\prime}$ & $-521 /-540$ & Promoter & $60.3 ; 63.0$ \\
\hline $5^{\prime}$ tcccactcggggaatgtg $3^{\prime}$ & $-572 /-555$ & & \\
\hline $5^{\prime}$ tgagttcatgtcgggatgg $3^{\prime}$ & $-365 /-383$ & Promoter & 59.3 \\
\hline $5^{\prime}$ ggattttgtttttaagccottg $3^{\prime}$ & $-419 /-398$ & & \\
\hline 5'aaggaaggagatggagatgct $3^{\prime}$ & $-231 /-251$ & Promoter & $61.2 ; 63.0$ \\
\hline $5^{\prime}$ agtgctgtctccaagcacct3' & $-298 /-279$ & & \\
\hline $5^{\prime}$ agtccaatggecctgaaac $3^{\prime}$ & $+37 /+19$ & Promoter and exon 1 & 57.5 \\
\hline 5'tccagtaccagcaacagcag $3^{\prime}$ & $-19 /+1$ & & $62.0 \cdot 64.0$ \\
\hline 5'agggaggggagggaggtag $3^{\prime}$ & $+96 /+78$ & Exon 1 & $62.0 ; 64.0$ \\
\hline $5^{\prime}$ cttctcttccccetgcttct $3^{\prime}$ & $+3674 /+2693$ & Exon 2 & $600 \cdot 610$ \\
\hline 5'ggggcctccacagagaata3' & $+3830 /+3812$ & Exon 2 & $60.0 ; 61.0$ \\
\hline 5'gcttacagectggttctcca3' & $+7124 /+7143$ & & \\
\hline 5'atgagegaaagagaaaattgat3' & $+7481 /+7460$ & Exon 3 & 3 \\
\hline 5' cacaatcaaaacctttctgcaa $3^{\prime}$ & $+7916 /+7937$ & Exon 4 & $56.1 ; 59.7$ \\
\hline 5' aaatgctgagaaaccagagca 3 ' & $+8128 /+8108$ & & \\
\hline $\begin{array}{l}5^{\prime} \text { ggaactctctccccaatgtg } 3^{\prime} \\
5^{\prime} \text { tttccttatggagcacatataatca } 3^{\prime}\end{array}$ & $\begin{array}{l}+9918 /+9937 \\
+10221 /+10197\end{array}$ & Exon 5 & $59.0 ; 62.0$ \\
\hline 5'tgaactccaaagccttattaggaa $3^{\prime}$ & $+11545 /+11568$ & & 58.4 .600 .610 \\
\hline $5^{\prime}$ gectccgtaaaactgaccaa $3^{\prime}$ & $+11804 /+11785$ & Exon 6 & $58.4 ; 60.0 ; 61.0$ \\
\hline $5^{\prime}$ aggggtcttcacagctttcc $3^{\prime}$ & $+13642 /+13661$ & & 600.632 \\
\hline 5' ccaatcatatccctgcatcc $3^{\prime}$ & $+13875 /+13856$ & Exon 7 & $60.9 ; 63.2$ \\
\hline $5^{\prime}$ tagcttccatggeagtcctc $3^{\prime}$ & $+15315 /+15334$ & UTR & 59 \\
\hline 5'gggattccagattttctttgc $3^{\prime}$ & $+15524 /+15504$ & UIR & 59.1 \\
\hline
\end{tabular}

Primer spanning region relates to DNA sequence numbering, with +1 as the first transcribed nucleotide. Gene bank accession numbers were AF404773 for IL12A (p35) and AY008847 for IL12B (p40).

DHPLC, denaturating high performance liquid chromatography analysis.

Table 2 Genotype frequencies and Hardy-Weinberg equilibrium analysis of the three single nucleotide polymorphisms studied

\begin{tabular}{|c|c|c|c|c|}
\hline Gene SNP & Genotype (fr & & & HWE \\
\hline $\begin{array}{l}\text { IL12A -504 } \\
\text { IL12A +6686 } \\
\text { IL12B + } 15485\end{array}$ & $\begin{array}{l}G / G(0.01) \\
A / A(0.03) \\
A / A(0.74)\end{array}$ & $\begin{array}{l}G / T(0.22) \\
A / G(0.22) \\
A / C(0.23)\end{array}$ & $\begin{array}{l}T / T(0.77) \\
G / G(0.75) \\
C / C(0.03)\end{array}$ & $\begin{array}{l}\chi 2=2.46, \mathrm{NS} \\
\chi 2=3.40, \mathrm{NS} \\
\chi 2=3.33, \mathrm{NS}\end{array}$ \\
\hline
\end{tabular}

HWE, Hardy-Weinberg equilibrium; SNP, single nucleotide polymorphism. 
culture and genotyping. An EDTA- $\mathrm{K}_{3}$ treated blood sample was obtained from all patients for host genomic DNA isolation.

A second series of 110 unrelated Italian patients (66 male, 44 female; age range 34 to 90 years) who underwent surgery for non-cardia gastric cancer was also studied. TNM stages were: TNM IA (4); TNM IB (7); TNM II (30); TNM IIIA (18); TNM IIIB (10); and TNM IV (41). According to the Lauren description of gastric cancers, tumours were classified as "intestinal-type" in 82 patients and "diffuse" in 28. Two tissue samples for H pylori genotyping and genomic DNA analysis were obtained from 50 non-cardia gastric cancer patients: one from the neoplastic area and another from the adjacent (but at least $3 \mathrm{~cm}$ distant) non-neoplastic mucosa. The tissue samples were stored at $-80^{\circ} \mathrm{C}$ until DNA extraction was carried out. Whole blood from all patients with non-cardia gastric cancer was used to obtain genomic DNA. Sera were also obtained for measurement of anti$H$ pylori antibodies.

\section{Histological evaluation}

In mucosal biopsies from patients who underwent EGDS, $H$ pylori colonisation density, chronic inflammation, polymorphonuclear cell infiltration (activity), and intestinal metaplasia were evaluated and graded according to the updated Sydney system. ${ }^{8}$ Non-cardia gastric cancer diagnosis was always confirmed histologically on samples taken intraoperatively.

\section{$H$ pylori culture and genotyping}

In the series of 251 patients who underwent EGDS, $H$ pylori was cultured as described elsewhere. ${ }^{10}$ DNA extracted from positive colonies was used to amplify ureA, $\operatorname{cag} A$, and vacA under conditions specified by us elsewhere. ${ }^{7}$ In the subgroup of 50 non-cardia gastric cancer patients for whom tissue samples were available, $H$ pylori infection and strain virulence gene characterisation were assessed in DNA extracted from tissue. UreA, cagA, and sl/s2 vacA were multiplex polymerase chain reaction (PCR) amplified in a $25 \mu \mathrm{l}$ final reaction volume containing: 150 ng DNA, $1 \times$ PCR gold buffer (Applied Biosystems, Foster City, California, USA), $1.5 \mathrm{mM} \mathrm{MgCl}, 200$ $\mu \mathrm{M}$ each dNTPs, $500 \mathrm{nM}$ primer URE-A $\mathrm{F}$ and URE-A R (5'gacatcactatcaacgaagg $3^{\prime}$ and 5' $5^{\prime}$ gaaaaccacgctctttag $\left.3^{\prime}\right), 160$ nM primer Cag-A F and Cag-A R (5'tcaaatacaccaacgcctcc 3' and 5'agcttcttgtggggacaatc3'), $600 \mathrm{nM}$ primer S1/2-F and S1/

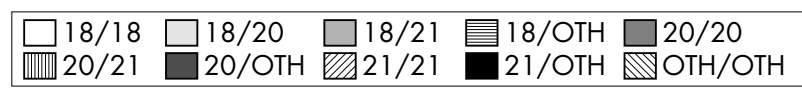

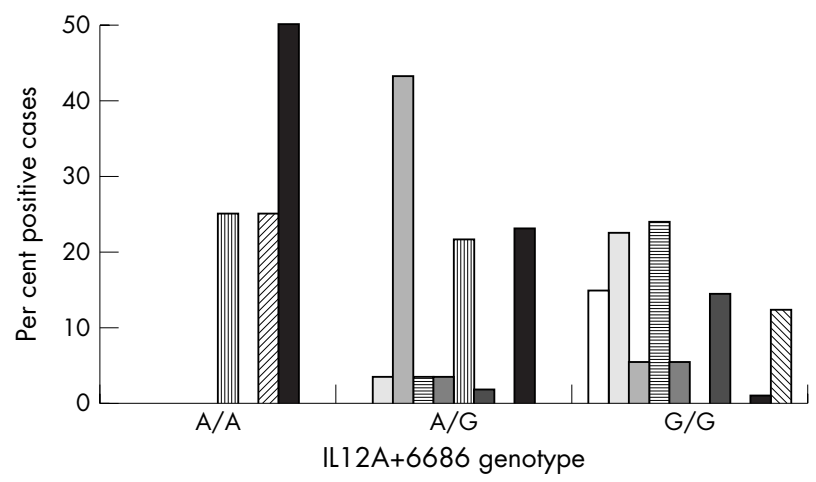

Figure 1 Association between IL12A variable number tandem repeats (VNTR) and IL12A+6686 genotypes. We genotyped IL12A VNTRs by considering separately the most common alleles $\left((\mathrm{GT})_{18},(\mathrm{GT})_{20}\right.$, and $(G T)_{21}$ ) and combining all the remaining alleles as "others" (OTH).
2-R (5'atggaaatacaacaaacacac3' and 5'ctgcttgaatgcgccaaac3'), and $2.5 \mathrm{U}$ AmpliTaq gold (Applied Biosystems). The thermocycling conditions were: $95^{\circ} \mathrm{C}$ for six minutes, then 42 cycles at $94^{\circ} \mathrm{C}$ for 30 seconds, $62^{\circ} \mathrm{C}$ for 30 seconds, $72^{\circ} \mathrm{C}$ for 30 seconds, and finally $72^{\circ} \mathrm{C}$ for seven minutes. The fragments (323 base pairs (bp) for ureA, 194 bp for cagA, and 259 or $286 \mathrm{bp}$ for s1 and s2 vacA, respectively) were separated by electrophoresis on $2 \%$ NuSieve $1 \%$ Seakem agarose gel (BMA, Rockland, Maine, USA) and stained with ethidium bromide. The PCR amplification conditions used for $\mathrm{ml} / \mathrm{m} 2$ vacA are described by us elsewhere. ${ }^{7}$ Past or actual $H$ pylori infection in the remaining 60 non-cardia gastric cancer patients was established on the basis of positive findings from serum anti-H pylori antibodies (Inova Diagnostics, San Diego, California, USA).

\section{Genomic DNA extraction and PCR amplification}

Genomic DNA was extracted from $3 \mathrm{ml}$ blood samples using the QIAamp DNA blood midi kit (Qiagen, Hilden, Germany). Promoters, coding sequences, splicing sites, and UTR regions of ILI2A and ILI2B were PCR amplified using the primers listed in table 1 . Briefly, $100 \mathrm{ng}$ of extracted DNA were amplified in a $50 \mu \mathrm{l}$ final reaction volume under the following conditions: $1 \times$ DNA polymerase gold buffer (Applied Biosystems), $1.5 \mathrm{mM} \mathrm{MgCl} 2,200 \mu \mathrm{M}$ each dNTPs, $500 \mathrm{nM}$ each primer, and $2.5 \mathrm{U}$ AmpliTaq gold (Applied Biosystems). PCR conditions were: $94^{\circ} \mathrm{C}$ for seven minutes, then 40 cycles at $94^{\circ} \mathrm{C}$ for 30 seconds, $60^{\circ} \mathrm{C}$ for 30 seconds, $72^{\circ} \mathrm{C}$ for 60 seconds, and finally $72^{\circ} \mathrm{C}$ for 20 minutes.

\section{DHPLC analyses}

PCR amplicons were analysed using a DHPLC screening strategy to detect any sequence polymorphisms (Transgenomic, Omaha, Nebraska, USA). This system uses the principles of reverse phase ion pair high performance liquid chromatography (RP-IP-HPLC) to carry out analytical separations of heteroduplexes. Table 1 reports temperatures for DHPLC analysis. The types of DNA polymorphism and their positions were defined by fluorescence dye terminator cycle sequencing on an ABI PRISM 310 genetic analyser (Applied Biosystems). Data were analysed with Sequencing Analysis 3.3 Software.

\section{Capillary electrophoresis}

$I L 12 A$ intron 6 and IL12B intron 4 VNTRs polymorphisms were studied by capillary electrophoresis. Samples (100 ng) of genomic DNA were PCR amplified in a total reaction volume of $20 \mu \mathrm{l}$ containing $\mathrm{I} \times \mathrm{PCR}$ buffer with $1.5 \mathrm{mM}$ $\mathrm{MgCl}_{2}, 200 \mu \mathrm{M}$ each dNTP, $1.25 \mathrm{U}$ AmpliTaq DNA polymerase (Applied Biosystems), and $500 \mathrm{nM}$ of the following dye labelled primer pairs: HEX-5'tgacgaggacatgggataaa3' and 5'aagctcattgcctttcaaaca3' for IL12A, and FAM-5'cagaggg gaaaaggatggtt $3^{\prime}$ and $5^{\prime}$ cctggccagaactttttcaa3' for IL12B. The temperature profile was: pre-PCR denaturation of seven minutes at $94^{\circ} \mathrm{C} ; 30$ seconds at $94^{\circ} \mathrm{C} ; 30$ seconds at $55^{\circ} \mathrm{C}$; and one minute at $72^{\circ} \mathrm{C}$ for 30 cycles, and a final extension of 30 minutes at $72^{\circ} \mathrm{C}$. Samples for capillary electrophoresis were prepared using $2 \mu \mathrm{l}$ of amplified products, added to $20 \mu \mathrm{l}$ deionised formamide and $0.5 \mu \mathrm{l}$ GeneScan -500 ROX size standard (Applied Biosystems). The mixtures were heated at $95^{\circ} \mathrm{C}$ for three minutes and snap cooled at $4^{\circ} \mathrm{C}$ for three minutes. The samples were detected by using an ABI PRISM 310 genetic analyser with a $47 \mathrm{~cm} \times 50 \mu \mathrm{m}$ capillary. Results were analysed using GeneScan Analysis software 3.7. The expected size ranges of the two polymorphisms were: IL12A VNTR (149-161 bp), IL12B VNTR (237-245 bp).

Allelic ladders for each VNTR were constructed by allele sequencing carried out on DNAs from homozygous samples. 
Table 3 Variable number tandem repeat (VNTR) allele frequencies of IL $12 A$ intron 6 and of IL12 B intron 4 found in the present series

\begin{tabular}{|c|c|c|c|c|c|}
\hline \multicolumn{3}{|c|}{ ILI2A VNTR } & \multicolumn{3}{|c|}{ IL12B VNTR } \\
\hline Allele & $\begin{array}{l}\text { No of }(G T)_{n} \\
\text { repeats }\end{array}$ & $\begin{array}{l}\text { Allele } \\
\text { frequency (\%) }\end{array}$ & Allele & $\begin{array}{l}\text { No of }(T G-T A)_{n} \\
\text { repeats }\end{array}$ & Allele frequency $(\%$ \\
\hline$(G T)_{11}$ & 11 & 0.1 & $(\mathrm{TG}-\mathrm{TA})_{8}$ & 8 & 0.8 \\
\hline$(G T)_{12}$ & 12 & 0.2 & $(\mathrm{TG}-\mathrm{TA})_{9}$ & 9 & 24.1 \\
\hline$(G T)_{15}$ & 15 & 0.5 & $(T G-T A)_{10}$ & 10 & 3.3 \\
\hline$(G T)_{16}$ & 16 & 5.6 & $(T G-T A)_{11}$ & 11 & 67.6 \\
\hline$(\mathrm{GT})_{17}$ & 17 & 5.9 & $(\mathrm{TG}-\mathrm{TA})_{12}$ & 12 & 3.9 \\
\hline$(G T)_{18}$ & 18 & 37.2 & $(\mathrm{TG}-\mathrm{TA})_{13}$ & 13 & 0.2 \\
\hline$(G T)_{19}$ & 19 & 9.7 & & & \\
\hline$(G T)_{20}$ & 20 & 21.3 & & & \\
\hline$(G T)_{21}$ & 21 & 13.8 & & & \\
\hline$(G T)_{22}$ & 22 & 5.1 & & & \\
\hline$(G T)_{23}$ & 23 & 0.8 & & & \\
\hline
\end{tabular}

\section{Statistical analysis}

Statistical analysis of data involved the $\chi^{2}$ test, logistic regression analysis, and the non-parametric Mann-Whitney U test.

\section{RESULTS}

$H$ pylori infection was diagnosed histologically in $36.4 \%$ of patients with no evident endoscopic lesions, $46.3 \%$ with antral gastritis, $43.6 \%$ with diffuse gastritis, $72.4 \%$ with duodenal ulcer, $77.8 \%$ with gastric ulcer, $36.4 \%$ with duodenitis, $60 \%$ with reflux gastritis, and $36.4 \%$ with oesophagitis. In patients with non-cardia gastric cancer, $H$ pylori infection was diagnosed on the basis of positive ureA findings in tissue samples in the subgroup of 50 non-cardia gastric cancer patients for whom tissue samples were available; in the remaining 60 non-cardia gastric cancer patients, $H$ pylori infection was established on the basis of positive findings from serum anti- $H$ pylori antibodies. Overall $H$ pylori infection was established in $69.4 \%$ of the non-cardia gastric cancer cases.

\section{IL I2A and IL I2B gene polymorphisms}

With DHPLC screening we identified three SNPs: two located in IL12A $(-504 \mathrm{G} / \mathrm{T}$ and $+6686 \mathrm{~A} / \mathrm{G})$ and one in ILI2B $(+15485 \mathrm{G} / \mathrm{T})$ genes, respectively. The nucleotide substitutions were defined by sequencing. All SNPs were in Hardy Weinberg equilibrium (table 2). The IL12A $-504 \quad \mathrm{G} / \mathrm{G}$ genotype was extremely rare ( $1 \%$ of the cases) and for this reason the four patients with this genotype were excluded from some of the statistical analyses. A significant association was found between ILI2A -504 and IL12A+6686 SNPs $\left(\chi^{2}=16.52, \mathrm{p}<0.01\right)$. In particular, the IL12A $-504 \mathrm{~T} / \mathrm{G}$ genotype was correlated with the $I L 12 A+6686 \mathrm{G} / \mathrm{G}$ genotype, while the IL12A $-504 \mathrm{~T} / \mathrm{T}$ genotype was correlated with IL12A +6686 A/A or A/G genotypes; no association was found between $I L 12 A-504$ and $I L 12 B+15485\left(\chi^{2}=1.18\right.$, NS) or between $I L 12 A+6686$ and $I L 12 B+15485\left(\chi^{2}=4.05\right.$, NS).

The number of GT repeats in intron 6 of IL12A (IL12A VNTR) and the number of TG-TA repeats in intron 4 of $I L 12 B$ (IL12B VNTR) varied widely when patients were considered overall. Table 3 shows the VNTR allele frequencies of $I L 12 \mathrm{~A}$ and $I L 12 \mathrm{~B}$ found in the present series. We genotyped IL12A and $I L 12 B$ VNTRs by selecting the most common alleles $\left((\mathrm{GT})_{18},(\mathrm{GT})_{20} \text {, and }(\mathrm{GT})_{21} \text { for IL12A VNTR; (TG-TA }\right)_{9}$ and $(\text { TG-TA })_{11}$ for IL12B VNTR) and combining them, as reported in table 4 . The IL12A VNTR genotypes (GT) $18 /(\mathrm{GT})_{20}$, (GT) $18 /$ $(\mathrm{GT})_{21},(\mathrm{GT})_{20} /(\mathrm{GT})_{20}$, and $(\mathrm{GT})_{20} /(\mathrm{GT})_{21}$ were significantly correlated with $I L 12 A-504 \mathrm{~T} / \mathrm{T}$, whereas $(\mathrm{GT})_{18} /(\mathrm{GT})_{\text {others }}$ $(\mathrm{GT})_{20} /(\mathrm{GT})_{\text {others, }}$ and $(\mathrm{GT})_{\text {others }} /(\mathrm{GT})_{\text {others }}$ were correlated with the IL12A $-504 \mathrm{~T} / \mathrm{G}$ genotype $\left(\chi^{2}=68.59, \mathrm{p}<0.001\right)$. The IL12A VNTR genotypes (GT) ${ }_{18} /(\mathrm{GT})_{18},(\mathrm{GT})_{18} /(\mathrm{GT})_{20}$, $(\mathrm{GT})_{18} /(\mathrm{GT})_{\text {others, }}(\mathrm{GT})_{20} /(\mathrm{GT})_{\text {others }}$ and $(\mathrm{GT})_{\text {others }} /(\mathrm{GT})_{\text {others }}$ were correlated with the $I L 12 A+6686 \mathrm{G} / \mathrm{G}$ genotype, whereas $(\mathrm{GT})_{18} /(\mathrm{GT})_{21}, \quad(\mathrm{GT})_{20} /(\mathrm{GT})_{21}$, and $(\mathrm{GT})_{21} /(\mathrm{GT})_{\text {others }}$ were correlated with the $I L 12 A+6686$ A/G genotype $\left(\chi^{2}=244.51\right.$, $\mathrm{p}<0.001$ ) (fig 1). The IL12B VNTR genotype was correlated

Table 4 Variable number tandem repeat (VNTR) genotype frequencies of IL12A intron 6 and of ILI 2 B intron 4 found in the present series

\begin{tabular}{|c|c|c|c|c|c|}
\hline \multicolumn{3}{|l|}{ IL12A VNTR } & \multicolumn{3}{|l|}{ IL12B VNTR } \\
\hline Genotype & $\begin{array}{l}\text { No of }(G T)_{n} \\
\text { repeats }\end{array}$ & $\begin{array}{l}\text { Genotype } \\
\text { frequency } \\
\text { (\%) }\end{array}$ & Genotype & $\begin{array}{l}\text { No of (TG-TA })_{n} \\
\text { repeats }\end{array}$ & $\begin{array}{l}\text { Genotype } \\
\text { frequency } \\
(\%)\end{array}$ \\
\hline$(G T)_{18} /(G T)_{18}$ & $18 / 18$ & 12.4 & $(\text { TG-TA })_{9} /(\text { TG-TA })_{9}$ & $9 / 9$ & 6.1 \\
\hline$(\mathrm{GT})_{18} /(\mathrm{GT})_{20}$ & $18 / 20$ & 17.8 & $(\mathrm{TG}-\mathrm{TA})_{9} /(\mathrm{TG}-\mathrm{TA})_{11}$ & $9 / 11$ & 31.5 \\
\hline$(\mathrm{GT})_{18} /(\mathrm{GT})_{21}$ & $18 / 21$ & 12.7 & $(\mathrm{TG}-\mathrm{TA})_{9} /(\mathrm{TG}-\mathrm{TA})_{\text {others }}$ & $9 /$ others & 4.1 \\
\hline$(\mathrm{GT})_{18} /(\mathrm{GT})_{\text {others }}$ & 18/others & 19.4 & $(\text { TG-TA })_{11} /(\text { TG-TA })_{11}$ & $11 / 11$ & 50.3 \\
\hline$(\mathrm{GT})_{20} /(\mathrm{GT})_{20}$ & $20 / 20$ & 4.1 & $(\mathrm{TG}-\mathrm{TA})_{11} /(\mathrm{TG}-\mathrm{TA})_{\text {others }}$ & 11 /others & 3.8 \\
\hline$(G T)_{20} /(G T)_{21}$ & $20 / 21$ & 4.8 & (TG-TA $)_{\text {others }} /$ others & Others/others & 4.1 \\
\hline$(G T)_{20} /(G T)_{\text {others }}$ & 20 /others & 11.5 & & & \\
\hline$(\mathrm{GT})_{21} /(\mathrm{GT})_{21}$ & $21 / 21$ & 1.3 & & & \\
\hline$(\mathrm{GT})_{21} /(\mathrm{GT})_{\text {others }}$ & 21 /others & 7.3 & & & \\
\hline$(G T)_{\text {others }} /(\mathrm{GT})_{\text {others }}$ & Others/others & 8.6 & & & \\
\hline
\end{tabular}




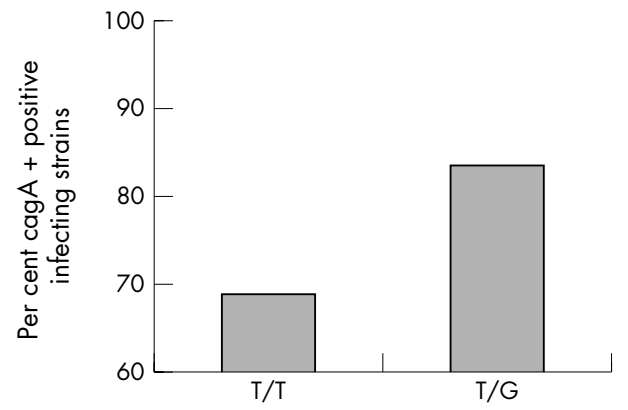

IL12A-504 genotype

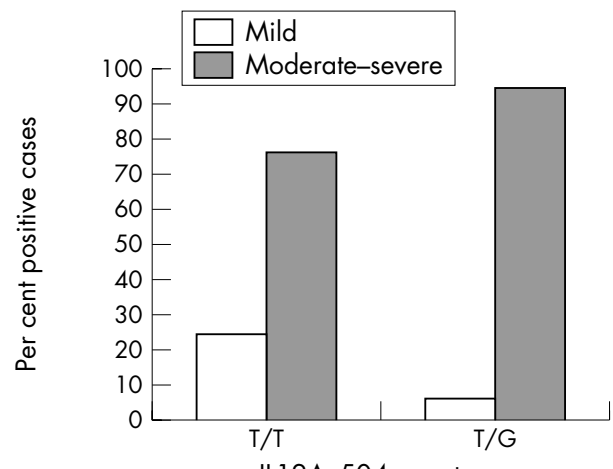

IL12A-504 genotype

Figure 2 Associations between IL12A - 504 SNP and cagA or antral activity in $\mathrm{H}$ pylori positive patients.

with $I L 12 B+15485\left(\chi^{2}=24.04, \mathrm{p}<0.01\right)$; in particular, the genotypes $(\mathrm{TG}-\mathrm{TA})_{9} /(\mathrm{TG}-\mathrm{TA})_{9},(\mathrm{TG}-\mathrm{TA})_{9} /(\mathrm{TG}-\mathrm{TA})_{11}$, and $(\mathrm{TG}-$ TA $)_{9} /(\mathrm{TG}-\mathrm{TA})_{\text {others }}$ were correlated with $I L 12 B+15485 \mathrm{~A} / \mathrm{A}$, whereas the $(\mathrm{TG}-\mathrm{TA})_{11} /(\mathrm{TG}-\mathrm{TA})_{11}$ genotype was correlated with $I L 12 B+15485 \mathrm{~A} / \mathrm{G}$ and $\mathrm{G} / \mathrm{G}\left(\chi^{2}=24.04, \mathrm{p}<0.01\right)$.

\section{IL $12 A$ and IL I2B polymorphisms and $H$ pylori infection}

$I L 12 A$ and IL12B SNPs or VNTRs were not correlated with $H$ pylori infection, cagA, $\mathrm{s}$ or $\mathrm{m}$ vacA, antral or body inflammation, and antral activity. Body activity was correlated with $I L 12 B$ VNTR: mild to moderate body activity was more commonly recorded in patients with the (TG-TA) $)_{11} /$ (TG-TA $)_{11}$ genotype $\left(\chi^{2}=47.75, \mathrm{p}<0.001\right)$.

In relation to $H$ pylori positive patients, the only associations we found were those between IL12A -504 SNP and cagA (Fisher's exact test, $\mathrm{p}<0.05$; odds ratio $=2.34,95 \%$

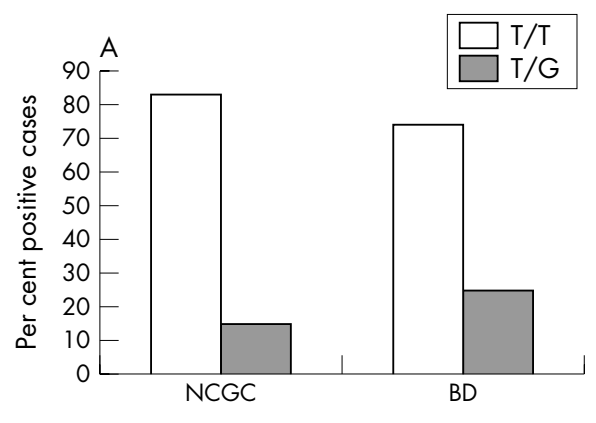

confidence interval (CI), 0.91 to 5.98$)$ or IL12A -504 SNP and antral activity $\left(\chi^{2}=8.83, \mathrm{p}<0.05\right)$ (fig 2$)$.

\section{ILI2A and ILI2B polymorphisms and H pylori associated diseases}

Among the five IL12 genetic polymorphisms studied, and when considering the patients overall, no statistically significant association was found with the disease diagnosis. The patients were then subdivided into two main groups: those with non-cardia gastric cancer and those with benign diseases. H pylori infection was more often recorded in noncardia gastric cancer patients $(69.4 \% v 49.0 \%)$ (Fisher's exact test: $\mathrm{p}<0.01)$. On considering $H$ pylori infected patients only, non-cardia gastric cancer was correlated with cagA (Fisher's exact test, $\mathrm{p}<0.05$ ) and sl vacA (Fisher's exact test, $\mathrm{p}<0.05$ ).

The frequency of non-cardia gastric cancer was higher in patients with the IL12A $-504 \mathrm{~T} / \mathrm{T}$ genotype (Fisher's exact test, $\mathrm{p}<0.05$ ) and in those with $I L 12 B$ VNTR $\left(\right.$ TG-TA) ${ }_{9} /($ TGTA $)_{11}$ genotype $\left(\chi^{2}=12.40, \mathrm{p}<0.05\right)$ (fig 3$)$.

Table 5 shows the association between IL12B VNTR polymorphism and the risk of gastric cancer. We selected subjects homozygous for the most common allele (TG-TA) ${ }_{11}$ as the reference group in the initial odds ratio estimations. The ILI2B VNTR (TG-TA) 9 /(TG-TA) 11 genotype was confirmed to increase the risk of gastric cancer, while (TG-

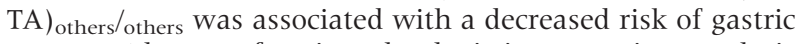
cancer. When performing the logistic regression analysis considering the diagnosis of gastric adenocarcinoma as a dependent variable and the gene polymorphisms of IL $12 \mathrm{~A}$ $-504, I L 12 B$ VNTR, and cagA as predictors, the odds ratios were 2.38 ( $95 \%$ CI, 0.96 to 5.88 ), 1.36 ( 1.05 to 1.76 ), and 1.68 (0.84 to 3.35$)$, respectively. None of the ILl2 gene polymorphisms studied was correlated with Lauren's non-cardia gastric cancer classification.

In relation to patients with benign diseases, we analysed the association between the precancerous intestinal metaplasia and $H$ pylori infection, $H$ pylori virulence genes, and IL12 gene polymorphisms. Intestinal metaplasia was significantly correlated with $H$ pylori infection $\left(\chi^{2}=10.05\right.$, $\mathrm{p}<0.01)$, cagA $\left(\chi^{2}=28.70, \mathrm{p}<0.001\right)$, sl vacA $\left(\chi^{2}=26.18\right.$, $\mathrm{p}<0.001)$, and with $\mathrm{ml}$ vacA $\left(\chi^{2}=6.64, \mathrm{p}<0.01\right)$, but not with IL12A or IL12B gene polymorphisms.

\section{DISCUSSION}

Using the DHPLC screening strategy followed by direct sequencing we identified the following polymorphisms: IL $12 A-504 \mathrm{~T} / \mathrm{G}, I L 12 A+6686 \mathrm{~A} / \mathrm{G}$, and ILI2B $+15485 \mathrm{~A} / \mathrm{C}$. The first SNP was located in the promoter region of the IL12A gene, while the latter two were localised in the UTR regions of the two genes. These three polymorphisms were in Hardy

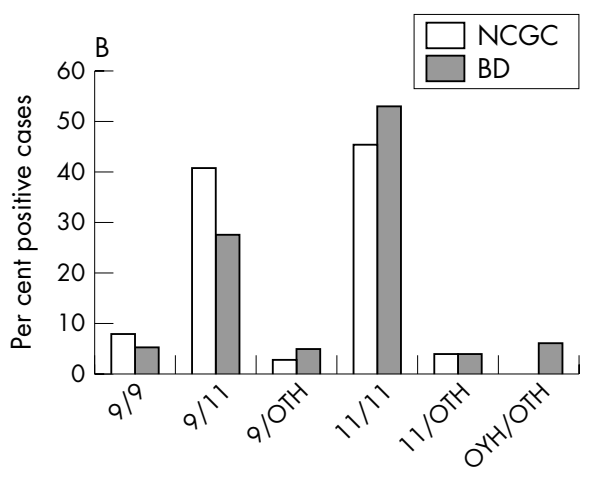

Figure 3 Association between non-cardia gastric cancer and ILI2A - 504 and IL12B variable number tandem repeat (VNTR) genotypes. We genotyped ILI2B VNTRs by considering separately the most common alleles ((TG-TA $)_{9}$ and $\left.(T G-T A)_{11}\right)$ and combining all the remaining alleles as "others" (OTH). BD, benign diseases; NCGC, non-cardia gastric cancer. 
Table 5 Association between IL 12B VNTR polymorphism and gastric cancer risk

\begin{tabular}{|c|c|c|c|c|}
\hline Genotype & $\begin{array}{l}\text { Case (gastric } \\
\text { adenocarcinoma) }\end{array}$ & $\begin{array}{l}\text { Control (benign } \\
\text { gastroduodenal diseases) }\end{array}$ & OR & $95 \% \mathrm{Cl}$ \\
\hline$(T G-T A)_{11} /(T G-T A)_{11}$ & 47 & 111 & 1.00 & Reference \\
\hline$(\mathrm{TG}-\mathrm{TA})_{9} /(\mathrm{TG}-\mathrm{TA})_{9}$ & 8 & 11 & 1.42 & 0.79 to 2.53 \\
\hline$(T G-T A)_{9} /(T G-T A)_{11}$ & 42 & 57 & $1.43^{*}$ & 1.02 to 1.99 \\
\hline$(T G-T A)_{9} /(T G-T A)_{\text {others }}$ & 3 & 10 & 0.77 & 0.28 to 2.15 \\
\hline$(T G-T A)_{11} /(T G-T A)_{\text {others }}$ & 4 & 8 & 0.89 & 0.39 to 2.06 \\
\hline (TG-TA) others / others & 0 & 13 & $0.70^{*}$ & 0.64 to 0.78 \\
\hline
\end{tabular}

Weinberg equilibrium. The two genes coding for the two IL12 subunits were also analysed for the number of dinucleotide repeats located in intron 6 and intron 4 for IL12A and IL12B, respectively. These VNTRs were studied bearing in mind that the amount of secreted protein might vary not only in relation to differences in the nucleotide sequence of the promoter or of the coding regions, but also in relation to intron VNTR, as already described for ILIRN, ${ }^{24}$ although the exact mechanism linking intron VNTR and protein synthesis has not yet been completely defined. The number of GT repeats of $I L 12 A$ VNTR varied in our patients from a minimum of 11 to a maximum of 23 , while TG-TA of $I L 12 B$ ranged from eight to 13 .

The wide range of the dinucleotide repeats for both VNTRs implies an excessive data dispersion whenever a statistical analysis is to be carried out. To overcome this limitation other investigators have classified the VNTR alleles of ILIRN on the basis of their length (long/short). ${ }^{29}$ This classification is feasible for ILIRN intron 2 VNTR, as each repeat corresponds to an oligonucleotide sequence of $86 \mathrm{bp}$, but it is difficult to apply to the present VNTRs as the maximum difference between the shorter and the longer alleles corresponds to only $24 \mathrm{bp}$. Therefore, in agreement with Cai et al, ${ }^{30}$ who studied the GT dinucleotide repeat polymorphism of the oestrogen receptor $\alpha$ gene, we classified the VNTR genotypes by considering the combinations of the most frequent alleles (three for $I L 12 A$ and two for $I L 12 B$ ) and by grouping the less frequent alleles as "others". Interestingly, significant associations were found between the VNTR genotypes and the SNPs of the corresponding gene. These associations might be the expression of linkage or of a selective advantage for some combinations over others.

None of the IL12A or IL12B polymorphisms and VNTRs studied was correlated with the presence or absence of $H$ pylori infection. We therefore suggest that the establishment of $H$ pylori infection depends on bacterial characteristics (urease production, expression of adhesins) ${ }^{1}$ more than on host cytokine gene polymorphisms, including IL12although a role has suggested for TNF $\alpha-308 \mathrm{G}$ to A transition. ${ }^{31}$ By contrast, cytokine gene polymorphisms may correlate with $H$ pylori virulence genes in $H$ pylori infected subjects. It has already been reported that TNF $\alpha$ polymorphisms are associated with infections from the more virulent cagA positive strains..$^{31}$ In the present paper, another association was recorded: between cagA and the IL12A - $504 \mathrm{~T} / \mathrm{G}$ genotype. This finding may be explained on the basis that an association between cag PAI and ILl2 has already been reported ${ }^{15}{ }^{16}$ : in infections caused by cag $A$ positive strains, enhanced gastric mucosal transcription of $I L 12 B$ is recorded, and enhanced release of IL12 by dendritic cells in vitro is found after exposure to cagE positive strains. IL12A -504 polymorphism might be involved in the regulation of gene expression and, consequently, of IL12 production. This nucleotide is contained within a site possibly recognised by the transcription factor AP2 $\left(\mathrm{GCCT}^{\mathrm{T}} / \mathrm{G} G \mathrm{GG}\right)$, with the penultimate base in our sequence being an A instead of a G. ${ }^{32}$ Using the program MATRIX SEARCH 1.0, ${ }^{33}$ which allows a search for potential transcription factor binding sites, the sequence with the G allele was recognised for AP2 binding with a match ratio of 0.74 , the range which denotes lack of exact match being 0.0 to 1.0. With the T allele, no match was found. The AP2 transcription factor can, in turn, be induced by IL6, ${ }^{34}$ potently stimulated by $H$ pylori. ${ }^{11-13}$ The IL $12 A-504$ $\mathrm{T} / \mathrm{G}$ genotype was also correlated with gastritis activity, which is scored on the basis of the degree of infiltrating polymorphonuclear cells. This finding might either be spurious and consequent on the prevalence of cagA positive infecting strains recorded in patients with this genotype, or be the result of an enhanced release of IL12, which is known to stimulate the production by $\mathrm{T}$ cells and natural killer cells of GM-CSF. ${ }^{18}$

We also investigated whether there was any association between IL12A or IL12B polymorphisms and $H$ pylori associated diseases. After the patients had been subdivided into two groups-one consisting of those with non-cardia gastric cancer and the other of those with benign gastroduodenal diseases-non-cardia gastric cancer was found to be correlated with the $I L 12 \mathrm{~A}-504 \mathrm{~T} / \mathrm{T}$ genotype and with the $I L 12 B$ VNTR (TG-TA) 9 /(TG-TA) 11 genotype, but also with $H$ pylori infection and its virulence determinants, cagA and sl vacA. For a better definition of the contribution of ILl2 gene polymorphisms in enhancing non-cardia gastric cancer risk in $H$ pylori infected subjects, logistic regression analysis was undertaken and both cagA, IL12A - 504 and IL12B VNTR polymorphisms were confirmed as risk factors for non-cardia gastric cancer. The onset of non-cardia gastric cancer can be considered the result of a process in which the complex interplay between $H$ pylori infection, host genetic background, and environmental factors creates conditions favouring or counteracting carcinogenesis. ${ }^{235} 36$ Taking into account the above hypotheses concerning the involvement of IL12A-504 SNP in the regulation of gene transcription, in $\mathrm{T} / \mathrm{T}$ homozygote subjects the transcription factor AP2 should have a limited transcriptional effect on IL12A, and this might lead to reduced IL12 production. It is known that lack of IL12 production results in a reduction in host resistance to infections and tumours ${ }^{37} 38$ and that treatment with IL12 has a marked anti-tumour effect on mouse carcinomas. ${ }^{37}$ It is more difficult to interpret the association between IL12B VNTR (TG-TA) ${ }_{9} /(\text { TG-TA })_{11}$ and (TG-TA) others $/($ TG-TA) others genotypes and gastric cancer risk. Increasing numbers of intronic VNTRs have been found to interfere with transcription processes, either by their effect on secondary DNA structure, by their action as protein binding sites, or by their influence on the transcription or stability of mRNA. ${ }^{24}{ }^{30}$ In addition, the VNTR polymorphism may be in linkage disequilibrium with exon alterations that may affect protein function. 
Non-cardia gastric cancer, "intestinal-type" in particular, is the end stage of a series of lesions which apparently represent a continuum of changes from normal to carcinoma. ${ }^{39}$ These include, in order of increasing severity, chronic gastritis, chronic atrophic gastritis, intestinal metaplasia, and dysplasia. In agreement with the multistep process hypothesis, patients with intestinal metaplasia are at increased risk of non-cardia gastric cancer. ${ }^{40}$ We therefore looked for an association between the presence or absence of intestinal metaplasia and IL12 gene polymorphisms on the one hand, and $H$ pylori infection and its virulent determinants on the other. A strong correlation was found between intestinal metaplasia and $H$ pylori infection, cagA, and vacA. None of the host genetic IL12 gene polymorphisms studied was correlated with intestinal metaplasia. This indicates that they do not play a role in determining this histopathological alteration. The association between IL12 polymorphisms and gastric cancer risk, but not with intestinal metaplasia, suggests that this cytokine probably plays an important role in the progression of intestinal metaplasia to dysplasia and cancer. IL12 gene polymorphisms may act by allowing dysplastic cells, originated from a normal mucosa or from intestinal metaplasia, to escape immune surveillance. This concept is in agreement with the lack of any association between IL12 gene polymorphisms and non-cardia gastric cancer histological subtypes, which are thought to be associated (intestinal type) or not (diffuse type) with the precancerous intestinal metaplasia. ${ }^{39}$

\section{Conclusions}

ILI2A and ILI2B gene polymorphisms may affect the latest steps of gastric carcinogenesis in $H$ pylori infected subjects. The exact mechanism underlying this phenomenon has yet to be defined, although it is reasonable to suggest that $I L 12 \mathrm{~A}$ -504 SNP and $I L 12 B$ VNTR may modulate IL12 production in response to $H$ pylori infection.

\section{ACKNOWLEDGEMENTS}

We wish to thank Mrs Monica Razetti (Department of Laboratory Medicine, University Hospital of Padua, Padua, Italy) for her assistance in the $H$ pylori culture and DNA extractions.

\section{Authors' affiliations}

F Navaglia, D Basso, N Gallo, A Falda, E Greco, M Plebani, Department of Laboratory Medicine, University Hospital of Padua, Padua, Italy

C-F Zambon, P Fogar, Department of Medical and Surgical Sciences, University of Padua

E Ponzano, L Caenazzo, Department of Environmental Medicine and Public Health, Section of Legal Medicine, University of Padua C Belluco, Department of Oncological and Surgical Sciences, University of Padua

F Di Mario, Department of Gastroenterology, University of Parma, Parma, Italy

M Rugge, Department of Pathology, University of Padua

Competing interests: none declared

Correspondence to: Professor Mario Plebani, Department of Laboratory Medicine, University Hospital of Padova, Via Giustiniani 2, 35128 Padova, Italy; mario.plebani@sanita.padova.it

\section{REFERENCES}

Montecucco C, Rappuoli R. Living dangerously: how Helicobacter pylori survives in the human stomach. Nature Rev 2001 2:457-66.

2 Kato I, Vivas J, Plummer M, Lopez G, Peraza S, Castro D, Sanchez V, Cano E, Andrade O, Garcia R, Franceschi S, Oliver W, Munoz N. Environmental factors in Helicobacter pylori-related gastric precancerous lesions in Venezuela. Cancer Epidemiol Biomarkers Prev 2004;13:468-76.

3 Atherton JC, Peek RM, Tham KT, Cover TL, Blaser MJ. Clinical and pathological importance of heterogeneity in vacA, the vacuolating cytotoxin gene of Helicobacter pylori. Gastroenterology 1997;112:92-9.
4 Basso D, Navaglia F, Brigato L, Piva MG, Toma A, Greco E, Di Mario F, Galeotti F, Roveroni G, Corsini A, Plebani M. Analysis of Helicobacter pylori vacA and cagA genotypes and serum antibody profile in benign and malignant gastroduodenal diseases. Gut 1998;43:182-6.

5 Yamaoka Y, Kwon DH, Graham DY. A Mr 34,000 proinflammatory outer membrane protein (oipA) of Helicobacter pylori. PNAS 2000;97:7533-8.

6 Mahdavi J, Sondén B, Hurtig M, Olfat FO, Forsberg L, Roche N, Angstrom J, Larsson T, Teneberg S, Karlsson K-A, Altraja S, Wadstrom T, Kersulyte D, Berg DE, Dubois A, Petersson C, Magnusson K-E, Norberg T, Lindh F, Lundskog BB, Arnqvist A, Hammarstrom L, Boren T. Helicobacter pylori SabA adhesin in persistent infection and chronic inflammation. Science 2002;297:573-8

7 Zambon C-F, Navaglia F, Basso D, Rugge M, Plebani M. Helicobacter pylori babA2, cagA, and s1 vacA genes work synergistically in causing intestinal metaplasia. J Clin Pathol 2003;56:287-91.

8 Dixon MF, Genta RM, Yardley JH, Correa P, and Participants in the International Workshop on the Histopathology of Gastritis, Huston 1994 Classification and grading of gastritis. The updated Sydney system. Am J Surg Pathol 1996:20:1161-81.

9 Warburton VJ, Everett S, Mapstone NP, Axon ATR, Hawkey P, Dixon MF. Clinical and histological associations of cagA and vacA genotypes in Helicobacter pylori gastritis. J Clin Pathol 1998;51:55-61.

10 Zambon C-F, Basso D, Navaglia F, Germano G, Gallo N, Milazzo M, Greco E, Fogar P, Mazza S, Di Mario F, Basso G, Rugge M, Plebani M Helicobacter pylori virulence genes and host IL-1RN and IL-1 beta genes interplay in favouring the development of peptic ulcer and intestinal metaplasia. Cytokine 2002;18:242-51

11 Basso D, Scrigner M, Toma A, Navaglia F, Di Mario F, Rugge M, Plebani M. Helicobacter pylori infection enhances mucosal interleukin-1, interleukin-6, and the soluble receptor of interleukin-2. Int J Clin Lab Res 1996;26:207-10.

12 Lindholm C, Quiding-Jarbrink M, Lonroth H, Hamlet A, Svennerholm A-M. Local cytokine response in Helicobacter pylori-infected subjects. Infect Immun 1998:66:5964-71.

13 Holck S, Norgaard A, Bennedsen M, Permin H, Norn S, Andersen LP. Gastric mucosal cytokine responses in Helicobacter pylori-infected patients with gastritis and peptic ulcers. Association with inflammatory parameters and bacterial load. FEMS Immunol Med Microbiol 2003;36:175-80.

14 Bauditz J, Ortner M, Bierbaum M, Niedobitek G, Lochs H, Schreiber S. Production of IL12 in gastritis relates to infection with Helicobacter pylori. Clin Exp Immunol 1999; 117:316-23.

15 Hida N, Shimoyama T, Neville P, Dixon MF, Axon ATR, Shimoyama T, Crabtree JE. Increased expression of IL-10 and IL12 (p40) mRNA in Helicobacter pylori infected gastric mucosa: relation to bacterial cag status and peptic ulceration. J Clin Pathol 1999;52:658-64

16 Guiney DG, Hasegawa P, Cole SP. Helicobacter pylori preferentially induces interleukin 12 (IL12) rather than IL-6 or IL-10 in human dendritic cells. Infect Immun 2003;71:4163-6.

17 Weigmann B, Neurath MF. T-bet and mucosal Th1 responses in the gastrointestinal tract. Gut 2002;51:301-3

18 Trinchieri G. Interleukin-12 and the regulation of innate resistance and adaptive immunity. Nature Rev Immunol 2003;3:133-46.

19 D'Elios MM, Manghetti M, De Carli M, Costa F, Baldari CT, Burroni D, Telford JL, Romagnani S, Del Prete G. T helper 1 effector cells specific for Helicobacter pylori in the gastric antrum of patients with peptic ulcer disease. J Immunol 1997;158:962-7.

20 Akhiani AA, Pappo J, Kabok Z, Schön K, Gao W, Franzén LE, Lycke N. Protection against Helicobacter pylori infection following immunization is IL12-dependent and mediated by Th1 cells. J Immunol 2002; 169:6977-84.

21 Ottenhoff THM, Verreck FAW, Lichtenauer-Kaligis EGR, Hoeve MA, Sanal O, van Dissel JT. Genetics, cytokines and human infectious disease: lessons from weakly pathogenic mycobacteria and salmonellae. Nature Genet 2002;32:97-105.

22 Skoog T, van't Hooft FM, Kallin B, Jovinge S, Boquist S, Nilsson J, Eriksson P, Hamsten $\mathrm{A}$. A common functional polymorphism ( $\mathrm{C} \rightarrow \mathrm{A}$ substitution at position -863 ) in the promoter region of the tumor necrosis factor- $\alpha$ (TNF- $\alpha$ ) gene associated with reduced circulating levels of TNF- $\alpha$. Hum Mol Genet 1999;8:1443-9.

23 Pravica V, Perrey C, Stevens A, Lee J-H, Hutchinson IV. A single nucleotide polymorphism in the first intron of the human IFN- $\gamma$ gene: absolute correlation with a polymorphic CA microsatellite marker of high IFN- $\gamma$ production. Hum Immunol 2000;61:863-6.

24 Hacker UT, Erhardt S, Tschop K, Jelinek T, Endres S. Influence of the IL-1Ra polymorphism on in vivo synthesis of the IL-1Ra and IL-1 $\beta$ after live yellow fever vaccination. Clin Exp Immunol 2001;125:465-9.

25 Hwang I-R, Kodama T, Kikuchi S, Sakai K, Peterson LE, Graham DY Yamaoka Y. Effect of interleukin 1 polymorphisms on gastric mucosa interleukin $1 \beta$ production in Helicobacter pylori infection. Gastroenterology 2002;123:1793-803.

26 Zambon C-F, Basso D, Navaglia F, Falda A, Belluco C, Fogar P, Greco E, Gallo N, Farinati F, Cardin R, Rugge M, Di Mario F, Plebani M. Increased risk of noncardia gastric cancer associated with proinflammatory cytokine gene polymorphisms. Gastroenterology 2004;126:382-3.

27 Morahan G, Huang D, Ymer SI, Cancilla MR, Stephen K, Dabadghao P, Werther G, Tait BD, Harrison LC, Colman PG. Linkage disequilibrium of a type 1 diabetes susceptibility locus with a regulatory IL12B allele. Nature Genet 2001;27:218-21.

28 Morahan G, Huang D, Wu M, Holt BJ, White GP, Kendall GE, Sly PD Holt PG. Association of IL12B promoter polymorphism with severity of atopic and non-atopic asthma in children. Lancet 2002;360:455-9.

29 Machado JC, Pharoah P, Sousa S, Carvalho R, Oliveira C, Figueiredo C, Amorim A, Seruca R, Caldas C, Carneiro F, Sobrinho-Simoes M. Interleukin 
IB and interleukin IRN polymorphisms are associated with increased risk of gastric carcinoma. Gastroenterology 2001;121:823-9.

30 Cai Q, Gao Y-T, Wen W, Shu X-O, Jin F, Smith JR, Zheng W. Association of breast cancer risk with a GT dinucleotide repeat polymorphism upstream of the estrogen receptor- $\alpha$ gene. Cancer Res 2003:63:5727-30.

31 Yea SS, Yang Y-I, Jang WH, Lee YJ, Bae H-S, Paik K-H. Association between TNF- $\alpha$ promoter polymorphism and Helicobacter pylori cagA subtype infection. J Clin Pathol 2001;54:703-6.

32 Faisst S, Meyer S. Compilation of vertebrate-encoded transcription factors. Nucleic Acids Res 1992;20:3-26.

33 Chen QK, Hertz GZ, Stormo GD. MATRIX SEARCH 1. 0: a computer program that scans DNA sequences for transcriptional elements using a database of weight matrices, Comp Appl Biosci 1995; 11:563-6.

34 Oyama N, Iwatsuki K, Homma Y, Kaneko F. Induction of transcription factor AP-2 by inflammatory cytokines in human keratinocytes. $J$ Invest Dermatol 1999;113:600-6.

35 Machado JC, Figueiredo C, Canedo P, Pharoah P, Carvalho R, Nabais S, Castro Alves C, Campos ML, van Doorn L-J, Caldas C, Seruca R, Carneiro F, Sobrinho-Simoes M. A proinflammatory genetic profile increases the risk for chronic atrophic gastritis and gastric carcinoma. Gastroenterology 2003;125:364-71

36 El-Omar EM, Rabkin CS, Gammon MD, Vaughan TL, Risch HA, Schoenberg JB, Stanford JL, Mayne ST, Goedert J, Blot WJ, Fraumeni JF, Chow W-H. Increased risk of noncardia gastric cancer associated with proinflammatory cytokine gene polymorphisms. Gastroenterology 2003; 124:1193-201.

37 Portielje JEA, Gratama JW, van Oijk HH, Stoter G, Kruit WHJ. IL12: a promising adjuvant for cancer vaccination. Cancer Immunol Immunother 2003:52:133-44.

38 Eguchi J-I, Hiroishi K, Ishii S, Mitamura K. Interferon-a and interleukin-12 gene therapy of cancer: interferon-a induces tumor-specific immune responses while interleukin-12 stimulates non-specific killing. Cancer Immunol Immunother 2003:52:378-86.

39 Ushijima T, Sasako M. Focus on gastric cancer. Cancer Cell 2004:5:121-5.

40 Dinis-Ribeiro M, Lopes C, da Costa-Pereira A, Guilherme M, Barbosa J, Lomba-Viana H, Silva R, Moreira-Dias L. A follow up model for patients with atrophic chronic gastritis and intestinal metaplasia. J Clin Pathol 2004;57:177-82.

\section{bmjupdates+}

bmjupdates+ is a unique and free alerting service, designed to keep you up to date with the medical literature that is truly important to your practice.

bmjupdates+ will alert you to important new research and will provide you with the best new evidence concerning important advances in health care, tailored to your medical interests and time demands.

\section{Where does the information come from?}

bmjupdates+applies an expert critical appraisal filter to over 100 top medical journals A panel of over 2000 physicians find the few 'must read' studies for each area of clinical interest

Sign up to receive your tailored email alerts, searching access and more...

www.bmjupdates.com 